\title{
Tetrazolium medium as an aid in the routine diagnosis of Candida ${ }^{1}$
}

\author{
MAIRE J. DENNY AND BETTY M. PARTRIDGE \\ From the Mycology Research Laboratory, Department of Bacteriology, \\ Charing Cross Hospital Medical School, London
}

SYNOPSIS The tetrazolium medium described is easily prepared and serves as a rapid, relatively accurate and simple means of differentiating Candida species, particularly $C$. albicans, from other yeasts. Culture on this medium does not replace other techniques used for yeast identification. No one test alone will suffice and final identification must rest on an overall pattern of characteristics. In the screening of 1,822 yeast isolates in this laboratory, culture on this medium has proved a valuable adjunct to other recognized techniques, and is now in regular use.

The rapid identification of Candida species is a common problem in routine laboratories. Not every yeast-like fungus seen in direct tissue smears or in culture is a Candida. Nor can it be assumed that in the isolation of Candida from man, only C. albicans is pathogenic and need be identified, since other species of Candida (C. tropicalis, C. pseudotropicalis, and $C$. stellatoidea) are known from experimental evidence to be pathogenic and have been recovered from disseminated infection in man (Hurley and Winner, 1964).

No single test is sufficient for full identification of Candida species (Drouhet). Yeasts not identified as Candida albicans by the germ-tube test (Reynolds and Braude, 1956) should not be discarded. If time allows, deep streaks in cornmeal agar will serve to identify $C$. albicans and other Candida species by their mycelial development and morphology, and sugar fermentations may be undertaken.

Pagano, Levin, and Trejo (1958) found that tetrazolium salts could be used as biological indicators to differentiate Candida species, depending on their ability to reduce them to insoluble, coloured formazans, deposited intracellularly. Although 'Pagano-Levin' medium, a nutrient agar incorporating a monotetrazolium salt, is relatively widely used for Candida studies in America, it is little used in Britain. Our assessment of this medium as an aid in laboratory diagnosis was made during the course of routine identification of yeasts isolated

${ }^{1}$ This work was supported by a grant from the Medical Research Council.

Received for publication 20 July 1967. from patients attending at the Charing Cross Group of Hospitals.

\section{METHODS AND MATERIALS}

The yeasts received in our laboratory for further investigation were those isolated in the routine bacteriology laboratories, usually on peptone-dextrose agar (without antibiotics) and sometimes blood agar, and usually subjected to a preliminary screening test for germ-tubes $\left(2-3 \mathrm{hr}\right.$ in horse serum at $\left.37^{\circ} \mathrm{C}\right)$ to detect probable Candida albicans strains.

On receipt of the yeast culture plates, the following procedures were adopted: macroscopically different colonial forms of yeasts were picked off and $(a)$ streaked into cornmeal agar plus $0.02 \%$ Tween 80 (deep streaks cut at an angle, without cover-slips or agar overlays) and incubated at $25^{\circ} \mathrm{C} ;(b)$ plated out on to tetrazolium medium and incubated at $37^{\circ} \mathrm{C}$.

To prepare the medium, dissolve $4 \%$ dextrose, $1 \%$ peptone (mycological), $0.1 \%$ beef extract (Lab. Lemco) in water, add agar $(1.5$ to $2 \%$ ) and autoclave (10 lb for 10 min). This nutrient medium may be held as stock and melted as required. To the melted, partially cooled agar, add $500 \mu \mathrm{g} / \mathrm{ml}$ of neomycin and $200 \mu \mathrm{g} / \mathrm{ml}$ of $2,3,5-$ triphenyltetrazolium chloride (TTC). The stock solution is made up of $100 \mathrm{mg} / \mathrm{ml}$ in distilled water, Seitz filtered and stored at $+4^{\circ} \mathrm{C}$. Final pH 5.5 to 6.0 .

On average, six to eight colonies were tested on each type of agar plate. Cornmeal plates were examined at 24-hour intervals for the presence of chlamydospores. Tetrazolium plates were examined for growth and colour changes after 24 hours (Fig. 1).

It was usually possible to differentiate as non-Candida species, those yeasts which failed to produce mycelium on cornmeal and gave poor growth on tetrazolium medium, although some produced coloured colonies.

Where confirmation of Candida species other than 


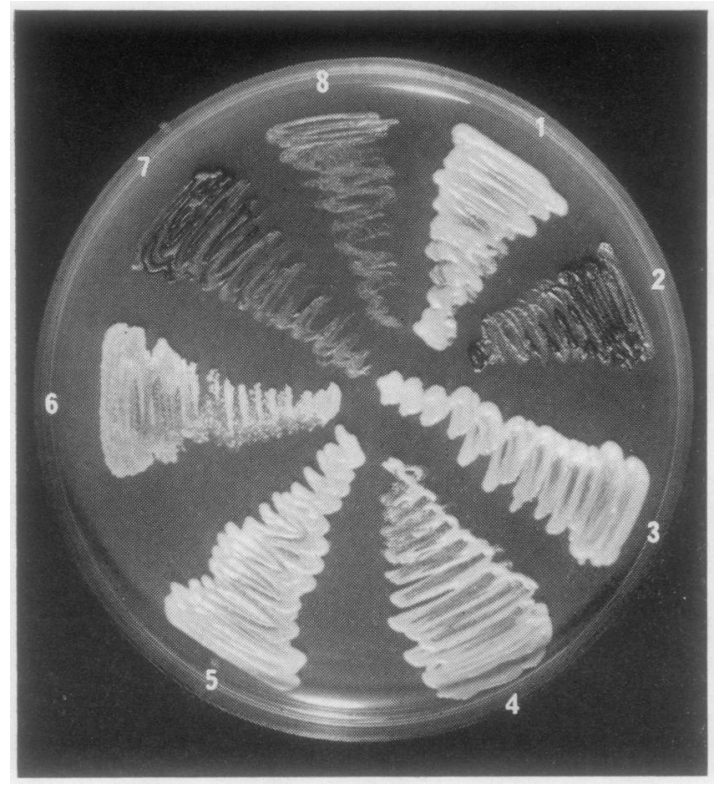

FIG. 1. Growth of Candida species on tetrazolium medium after 24 hours at $37^{\circ} \mathrm{C}$. Candida albicans, 1, 3, 5; C. tropicalis, 2, 7; C. krusei, 6; C. parapsilosis, 4; Torulopsis glabrata, 8 .

C. albicans was required, fermentation tests were carried out using $3 \%$ sugars (dextrose, sucrose, maltose, lactose, galactose, and raffinose). Carbon and nitrogen auxanograms were not determined owing to the time required for their preparation.

\section{RESULTS}

On triphenyltetrazolium chloride medium (TTC) Candida albicans strains grew easily, producing smooth, raised, glistening creamy-textured colonies, but showed no or limited ability to reduce the indicator salt, the colonies appearing cream t⿳亠丷厂巾 faintly pink (Fig. 1). Results were frequently. determined before chlamydospores had appeare in the cornmeal agar, which could be slow (up to 8 four days). If there were a positive result to botlo tests, the organism was recorded as $C$. albicans. Ir the absence of chlamydospores, but with a positive germ-tube test, strains were also recorded as C. albicans. Only very rarely was confirmation by sugar fermentations required.

Candida tropicalis strains usually developed as. rather dry, dark, maroon-red colonies on tetrazoliunfu medium. Although the colour was regarded as diagnostic for this species (Table I), the growth rate was variable and fermentation tests were usually carried out in addition. Similarly, other Candid $\dot{\alpha}$ species showed evidence of reducing the tetrae zolium, the coloured colonies produced ranging from pink to orange; fermentation results were used for confirmation. Only $C$. krusei failed to develop distinctive coloured colonies, but the flatov dry colonies of this species contrasted with the glistening growth of C. albicans (Fig. 1).

The incidence of mixed Candida species, isolate from the same specimen and not always clearlg visible in the original culture plate, occurred is $6 \%$ of the total Candida isolates (Table II a and $b$ ) $\frac{3}{\circ}$ these mixed isolates were easily detected on the्g tetrazolium medium. Candida albicans occurred a\& one of the organisms in the majority of mixe infections.

\section{DISCUSSION}

GERM TUBES The ability of $C$. albicans to form 'germ tubes' within two to three hours when incu 3 bated at $37^{\circ} \mathrm{C}$. in certain protein fluids, e.g. humai⿱ and animal serum (Taschdjian, Burchall, and Kozinn? 1960), plasma, cerebrospinal fluid, and raw egg

TABLE I

TESTS USED FOR IDENTIFICATION OF CANDIDA SPECIES

Test Medium

\begin{tabular}{llll}
\hline $\begin{array}{l}\text { Serum } \\
\text { (germ tubes) }\end{array}$ & $\begin{array}{l}\text { Tetrazolium (TTC) } \\
\text { Medium } \\
\text { (coloured colonies) }\end{array}$ & $\begin{array}{l}\text { Cornmeal Agar } \\
\text { (chlamydospores) }\end{array}$ & $\begin{array}{l}3 \% \text { Sugars } \\
\text { (fermentation) }\end{array}$
\end{tabular}

\begin{tabular}{|c|c|c|c|c|c|c|c|c|c|c|}
\hline $\begin{array}{l}\text { Period of incubation } \\
\text { Temperature }\end{array}$ & $\begin{array}{l}2-3 \mathrm{hr} \\
37^{\circ} \mathrm{C}\end{array}$ & $\begin{array}{l}24 \mathrm{hr} \\
37^{\circ} \mathrm{C}\end{array}$ & $\begin{array}{l}24-48 \mathrm{hr} \\
25^{\circ} \mathrm{C}\end{array}$ & \multicolumn{7}{|c|}{$\begin{array}{l}48 \mathrm{hr} \text { - several days } \\
37^{\circ} \mathrm{C}\end{array}$} \\
\hline Candida species & & & & $D$ & $M$ & $S$ & $L$ & $G a$ & $R a$ & Pellicle \\
\hline C. albicans & + & Cream (glistening) & + & + & + & \pm & - & \pm & - & - \\
\hline C. stellatoidea ${ }^{1}$ & \pm & Orange-pink & \pm & + & + & - & - & 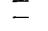 & - & - \\
\hline C. tropicalis & - & Dark, maroon-red & - & + & + & + & - & + & - & \pm \\
\hline C. pseudotropicalis & 一 & Salmon pink & - & + & - & + & + & \pm & + & - \\
\hline C. krusei & - & $\begin{array}{l}\text { White to pale } \\
\text { pink (dry) }\end{array}$ & - & + & - & - & - & $\overline{-}$ & - & + \\
\hline C. parapsilosis & - & Rose pink & - & + & - & \pm & - & \pm & - & - \\
\hline C. guilliermondii & - & Pink & - & + & - & + & - & \pm & + & - \\
\hline
\end{tabular}

${ }^{1}$ Regarded by some as a variant of $C$. albicans 
white (Buckley and Van Uden, 1963) is considered to be diagnostic for this Candida species alone. Reports have shown a relatively high degree of accuracy in identification with this technique (Mackenzie, 1962; Griffin, 1964). However, in the present survey, approximately $17 \%$ of $C$. albicans strains were incorrectly reported as negative by workers inexperienced in this field. This may have been due to failure to produce germ tubes within the specified time, or to the presence of other Candida and non-Candida species. Of the $C$. tropicalis strains, $50 \%$ were reported as producing germ tubes owing to confusion with development of elongated buds. This suggests that the results of germ tube tests used alone are unreliable.

CHLAMYDOSPORE PRODUCTION Seeliger (1955) and Taschdjian (1957) recommended the addition of $1 \%$ Tween 80 (a wetting agent) to cornmeal agar as a means of increasing chlamydospore production. We have found a weaker solution $(0.02 \%)$ to be more satisfactory. Als 0 , angled cuts into cornmeal plates (4-5 $\mathrm{mm}$ depth) obviated the necessity for covering the streaks with coverslips or agar overlays (Dawson, 1962) in order to obtain sufficient

TABLE IIa

DISTRIBUTION OF CANDIDA SPECIES ISOLATED FROM PATIENTS BETWEEN JULY 1965 AND JULY 1966

\begin{tabular}{llll} 
& $\begin{array}{l}\text { Fulham } \\
\text { Hospital }\end{array}$ & $\begin{array}{l}\text { Charing } \\
\text { Cross } \\
\text { Hospital }\end{array}$ & $\begin{array}{l}\text { Total } \\
\text { No. }\end{array}$ \\
\hline $\begin{array}{l}\text { Total no. of yeast isolates } \\
\begin{array}{l}\text { screened } \\
\text { Total no. of Candida }\end{array}\end{array}$ & 1,276 & 546 & 1,822 \\
$\begin{array}{l}\text { isolates } \\
\text { Total no. of yeasts not } \\
\begin{array}{l}\text { Candida species } \\
\text { (unidentified) }\end{array}\end{array}$ & 1,070 & 451 & $1,521(82 \cdot 5 \%)$ \\
& 206 & 95 & $301(17 \cdot 5 \%)$
\end{tabular}

anaerobiosis, and gave satisfactory mycelial development and chlamydospore production.

REDUCTION OF TETRAZOLIUM Various indicator compounds, other than tetrazolium salts, have been used in attempts to provide a simple method for detecting and differentiating species of Candida; these include bismuth sulphite (Nickerson, 1953), selenite and tellurite (Nickerson, Taber, and Falcone, 1956), and molybdenum(MacLaren and Armen, 1958).

We have found, during the course of routine screening and identifying over 1,500 Candida isolates from patients in the past year, that triphenyltetrazolium chloride acts as a satisfactory biological indicator when incorporated into a nutrient agar (a slightly fortified Sabouraud's agar). Candida species grow as well on this medium as on the routine peptone-dextrose (Sabouraud's) agar. Bacterial growth is inhibited by the addition of neomycin. Agar plates were found to be the most satisfactory for culture of specimens and isolates: many of the early studies were made using prepared tubes or vials $^{1}$, which may have accounted for the discrepancies reported.

Many investigators have used incubation temperatures of $25^{\circ}$ to $30^{\circ} \mathrm{C}$ (Pagano et al., 1958 ; Kutscher, Seguin, Zegarelli, Rankow, Campbell, and Mercadante, 1959a; Kutscher, Seguin, Zegarelli, Rankow, Mercadante, and Piro, 1959b; Hayes and Thompson, 1963; Schmidt, 1966), although Kelly, Kutscher, and Tuoti (1961) found no difference in the results of growth at room temperature and $37^{\circ} \mathrm{C}$. We found no necessity to use lower temperatures since sufficient growth and colour changes could be detected after 24 hours at $37^{\circ} \mathrm{C}$. Positive readings for $C$. albicans were frequently obtained before chlamydospores were seen on cornmeal agar. Sometimes, cultures on tetrazolium medium gave the ${ }^{1}$ Squibbs preparation: approximately $2 \mathrm{ml}$ agar slants.

TABLE IIb

DISTRIBUTION OF CANDIDA SPECIES ISOLATED FROM PATIENTS

Candida Species

Sputum Main Source of Isolates

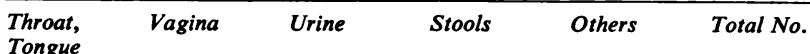

\begin{tabular}{|c|c|c|c|c|c|c|c|c|}
\hline$\left\{\begin{array}{l}\text { C. albicans } \\
\text { C. albicans and } \\
\text { C. tropicalis } \\
\text { C. albicans } \text { and other } \\
\text { Candida species } \\
\text { C. tropicalis } \\
\text { C. tropicalis and other } \\
\text { Candida species }\end{array}\right.$ & $\begin{array}{r}645 \\
38 \\
17 \\
101 \\
18\end{array}$ & 120 & 260 & $\begin{array}{l}2 \\
3 \\
5\end{array}$ & $\begin{array}{r}40 \\
1 \\
2 \\
1\end{array}$ & 42 & $\left.\begin{array}{r}1176 \\
44 \\
30 \\
119 \\
18\end{array}\right\}$ & 1,250 \\
\hline $\begin{array}{l}\text { C. pseudotropicalis } \\
\text { C. krusei } \\
\text { C. parapsilosis } \\
\text { C. guilliermondii } \\
\text { Candida species } \\
\text { (unidentified) }\end{array}$ & $\begin{array}{r}9 \\
21 \\
12 \\
2 \\
34\end{array}$ & $\begin{array}{l}4 \\
2\end{array}$ & $\begin{array}{l}2 \\
1 \\
5\end{array}$ & $\begin{array}{l}1 \\
5 \\
1\end{array}$ & 2 & $\begin{array}{l}19 \\
10\end{array}$ & $\left.\begin{array}{r}12 \\
32 \\
39 \\
2 \\
49\end{array}\right\}$ & 85 \\
\hline
\end{tabular}


only clue as to the identity of the yeast isolate. We found tetrazolium medium invaluable in checking the identity of 'rough' and 'smooth' colony forms, particularly of $C$. albicans and $C$. tropicalis. Also, in separating mixed Candida species, $C$. albicans showed as creamy, smooth colonies which differed from other Candida species either in texture or colour, as already described. Non-Candida yeasts generally grew poorly on tetrazolium medium and their identity could be checked from growth on cornmeal agar, sugar fermentations, etc.

Clinical specimens (sputum, swabs, urine, etc.) may be cultured direct on to tetrazolium agar plates. Satisfactory isolation and detection of Candida species has been described from vaginal specimens (Gillespie, Inmon, and Slater, 1960; Mendel, Haberman, and Hall, 1960) and mucosal and skin scrapings (Rosenthal and Furnari, 1960), though Sinski (1960) found that seven out of 23 yeasts isolated by this method gave false results.

\section{REFERENCES}

Buckley, H. R., and Van Uden, N. (1963). Sabouraudia, 2, 205.
Dawson, C. O. (1962). Ibid., 1, 214.

Drouhet, E. Les candidoses et leur diagnostic de laboratoire. Communi-으 cation des Laboratoires Squibb, Paris.

Gillespie, H. L., Inmon, W. B., and Slater, V. (1960). Obstet. and

Gynec., 16, 185.
Griffin, E. R. (1964). J. med. Lab. Technol., 21, 298.

Hayes, A., and Thompson, J. R. (1963). Amer J. clin. Path., 40, 553.

Hurley, R., and Winner, H. I. (1964). Mycopathologia (Den Haag), 24, 337.

Kelly, J., Kutscher, A. H., and Tuoti, F. (1961). J. invest. Derm., 36, 403 .

Kutscher, A. H., Seguin, L., Zegarelli, E. V., Rankow, R. M., ֶి Campbell, J. B., and Mercadante, J. (1959a). Antibiot. and Chemother., 9, 649.

$-, \frac{1}{\text { Derm., 33, }}, \frac{1}{4}$. - , and Piro, J. D. (1959b). J. invest.

Mackenzie, D. W. R. (1962). J. clin. Path., 15, 563.

Maclaren, J. A., and Armen, D. (1958). Amer. J. clin. Path., 30, 411 ,

Mendel, E. B., Haberman, S., and Hall, D. K. (1960). Obstet. and Gynec., 16, 180.

Nickerson, W. J., (1953). J. infect. Dis., 93, 43.

$\longrightarrow$, Taber, W. A., and Falcone, G. (1956). Canad. J. Microbiol., $\vec{\omega}$ 2,575 .

Pagano, J., Levin, J. D., and Trejo, W. (1958). Antibiotics Ann., 1957-58, 137.

Reynolds, R., and Braude, A. (1956). Clin. Res. Proc., 4, 40.

Rosenthal, S. A., and Furnari, D. (1960). J. invest. Derm., 34, 229.

Schmidt, J. A. (1966). Personal communication.

Seeliger, H. (1955). Z. Hyg. Infekt. -Kr., 141, 488.

Sinski, J. T. (1960). J. invest. Derm., 35, 131.

Taschdjian, C. (1957). Mycologia, 49, 332. Burchall, J. J., and Kozinn, P. J. (1960). Amer. J. Dis. Child., 